\title{
STUDI KASUS PEMBELAJARAN GEOMETRI ANALITIK
}

\author{
Rio Fabrika Pasandaran ${ }^{1}$, Mufidah ${ }^{2}$ \\ Universitas Cokroaminoto Palopo $^{1}$, Universitas Tadulako ${ }^{2}$ \\ riolovemath@gmail.com ${ }^{1}$, fida.mathc@ gmail.com ${ }^{2}$
}

\begin{abstract}
Abstrak
Penelitian ini berbentuk studi kasus yang bertujuan untuk mengungkap temuan-temuan praktis yang dapat dijadikan dasar dalam pengembangan pembelajaran Geometri Analitik, khusus pada materi irisan kerucut. Data penelitian dikumpulkan melalui teknik observasi, catatan lapangan dan tes hasil belajar. Hasil penelitian menunjukkan bahwa orientasi pembelajaran harus mengarah pada proses investigasi dengan prinsip identifikasi semua konsep yang mendasari konstruk definisi, aksioma, atau teorema (Geometry), integrasi konsepkonsep (secara sistematis) menjadi suatu prinsip (Occupation), analisis hubungan antar konsep yang membentuk suatu prinsip (Analitycal), membangun komunikasi interaktif dan hubungan ketergantungan sosial yang positif serta mengambil peran dan tanggung jawab secara individu dan berkelompok terhadap proses penyusunan pengetahuan secara koheren (Learning System)

Kata Kunci : Pembelajaran, Geometri Analitik
\end{abstract}

\section{A. Latar Belakang}

Pembelajaran Geometri Analitik di jenjang perkuliahan termasuk ke dalam skema pembelajaran yang kompleks. Di satu sisi mahasiswa harus memiliki pengetahuan, analisa, dan keterampilan dalam bidang aljabar dan di sisi lain, mereka juga harus membekali diri dengan kemampuan visual spasial, analitikal, dan proses rigor secara tepat dan efektif. Hasil penelitian Nur;aini (2017), menjelaskan bahwa Geometri mempelajari titik, garis, bidang dan ruang serta sifatsifat, ukuran-ukuran, dan keterkaitan satu dengan yang lain. Bila dibandingkan dengan bidang-bidang lain dalam matematika, geometri merupakan salah satu bidang dalam matematika yang dianggap paling sulit untuk dipahami. Tuntutan inilah yang menyebabkan pembelajaran geometri menjadi batu sandungan bagi sebagian besar mahasiswa. Jika tidak dikelola secara benar, maka akan menjadi masalah yang terus berulang dan berpeluang menciptakan kesan buruk dalam pengalaman kognitif mereka.

Di sisi lain, irisan kerucut merupakan salah satu topik yang luas. Kajiannya meliputi proses pembentukan kurva-kurva sebagai hasil pengirisan sebuah kerucut dengan posisi yang berbeda-beda. Kurva-kurva yang dimaksud meliputi; parabola, 
elips, dan hiperbola. Dalam pembelajaran irisan kerucut dibutuhkan penalaran khusus sedemikian hingga mahasiswa dapat mengidentifikasi berbagai bentuk persamaan yang mewakili tempat kedudukan tak hingga titik dalam bidang. selain itu, keterampilan prosedural juga harus dimiliki agar proses manipulasi aljabar dapat terjadi dengan baik dan sistematis. Fonna (2018), juga menjelaskan pengalaman empiriknya ketika mengajarkan Geometri. Berdasarkan hasil pengamatan yang dilakukan selama mengampu mata kuliah ini dan hasil diskusi dengan beberapa dosen pengampu mata kuliah yang sama, ternyata banyak mahasiswa yang mengalami kesulitan dalam pemahaman konsep geometri khususnya pada penyelesesaian soal titik dan vektor bidang, garis lurus, lingkaran serta persamaan irisan kerucut.

Berdasarkan permasalahan diatas, kami dapat menghimpun beberapa padanan fakta yang berhasil diidentifikasi dalam perkuliahan Geometri analitik (2 SKS) di Program studi Pendidikan Matematika Universitas Cokroaminoto Palopo. Secara khusus fakta-fakta tersebut berbentuk respon \& perilaku belajar mahasiswa dari waktu ke waktu yang diamati secara berkesinambungan. Beberapa kecenderungan yang terjadi diantaranya ;

(1) $85 \%$ mahasiswa hanya membaca materi tanpa melakukan identifikasi konsep awal

(2) Mahasiswa cenderung hanya membaca bagian-bagian tertentu seperti rumus, contoh soal, dan soal latihan tertentu

(3) Mahasiswa membutuhkan tampilan visual dinamis dari proses pembentukan kurva irisan kerucut

(4) Mahasiswa membutuhkan skema belajar yang bersifat semi kooperatif. Artinya, ada bagian materi yang harus dikuasai secara individu dan ada bagian materi yang dibahas secara berkelompok

(5) Mahasiswa membutuhkan sebuah frame atau konsep pembelajaran yang dapat mengakomodasi kebutuhan belajar

Berdasarkan kelima fakta tersebut, kami merancang sebuah skenario atau strategi pembelajaran yang memungkinkan setiap mahasiswa dapat;

(1) Menuliskan semua konsep yang mendasari konstruk definisi, aksioma, atau teorema (Geometry) 
(2) Mengintegrasikan konsep-konsep (secara sistematis) menjadi suatu prinsip (Occupation)

(3) Menganalisa hubungan antar konsep yang membentuk suatu prinsip (Analitycal)

(4) Membangun komunikasi interaktif dan hubungan ketergantungan sosial yang positif dengan sejawat dan dosen (Learning)

(5) Mengambil peran dan tanggung jawab secara individu dan berkelompok terhadap proses penyusunan pengetahuan secara koheren (System)

Kelima hal ini menjadi dasar dalam menyusun sebuah strategi belajar kontemporer khusus dalam pembelajaran geometri, yang selanjutnya dikenal dengan istilah Strategi Pembelajaran GOALS (Geometry Occupation Analitycal Learning System).

\section{B. Metode Penelitian}

Penelitian ini merupakan studi kasus yang dilakukan dengan pendekatan kualitatif \& kuantitatif di perkuliahan Geometri Analitik dengan topik Irisan Kerucut pada Mahasiswa Program Studi Pendidikan Matematika FKIP UNCP, Semester genap 2019-2020. Data penelitian berbentuk pernyataan dan argumen yang berasal dari hasil observasi dan catatan lapangan. Instrument utama penelitian adalah peneliti sendiri, sebagai pengumpul, pengolah, dan penafsir data, dibantu dengan instrument tambahan berupa catatan lapangan dan transkrip pembelajaran.

Fokus penelitian ini dirancang untuk mengungkapkan proses pembelajaran irisan kerucut melalui strategi GOALS (Geometry Occupation Analitycal Learning System). Respon atau bentuk-bantuk aktivitas mahasiswa akan dikategorikan ke dalam prinsip-prinsip yakni Geometry activity, occupation activity, analitycal activity, dan learning system melalui observasi yang mendalam. Observasi pembelajaran dilakukan selama 6 kali tatap muka sejak Februari-April 2020, dengan cara merekam seluruh aktivitas pembelajaran dari tahap awal sampai akhir. Setelah data terkumpul, dilanjutkan dengan proses validasi data melalui triangulasi. Triangulasi dilakukan dengan cara melihat kecocokan data dari setiap instrumen penelitian. Data yang terkumpul akan ditinjau sifat konsistensinya. Data yang konsisiten/relatif sama adalah data yang valid, dan dapat dilanjutkan dengan proses 
analisis data. Analisis data dilakukan dengan teknik Miles dan Huberman (Data Collection, Data Reduction, Data Display, Data Verification) secara interaktif dan berkelanjutan hingga memperoleh bentuk data yang berpola, dengan langkahlangkah sebagai berikut.

a. Mengumpulkan data melalui catatan lapangan, transkrip pembelajaran, dan video rekaman.

b. Reduksi data adalah kegiatan yang mengacu kepada proses menyeleksi, memfokuskan, mengabstraksikan, dan mentransformasikan data mentah. Reduksi data dalam penelitian ini dilakukan dengan membuat rangkuman yang terdiri dari: inti, proses, dan pernyataan-pernyataan yang sesuai dengan tujuan penelitian. Teknik validasi data yang digunakan dalam penelitian ini adalah perpanjangan pengamatan

c. Penyajian data yang meliputi pengklasifikasian dan identifikasi data, yaitu menuliskan kumpulan data yang terorganisir dan terkategori sehingga menghasilkan data valid.

d. Pemaparan data dan penafsiran data, berisi pembahasan data valid untuk menghasilkan temuan penelitian berdasarkan tujuan penelitian yang ditetapkan.

\section{Hasil dan Pembahasan}

Pembahasan berisi tentang kategorisasi setiap bentuk aktivitas belajar mahasiswa berdasarkan prinsip-prinsip pembelajaran GOALS (Geometry Occupation Analitycal Learning System). Aktivitas-aktivitas yang berhasil diidentifikasi selanjutnya dielaborasikan dengan teori yang relevan sehingga dapat membangun teori substantif baru sebagai berikut.

\section{a) Geometry}

Prinsip ini memuat aktivitas belajar mahasiswa dalam mengidentifikasi faktafakta/prinsip/konsep geometri. Proses identifikasi dilakukan dengan cara menuliskan semua fakta yang mendasari konstruk definisi, aksioma, atau teorema pada materi irisan kerucut. Sebagai stimulus, dosen memberikan beberapa ilustrasi pada pembahasan parabola \& elips sebagai berikut. 

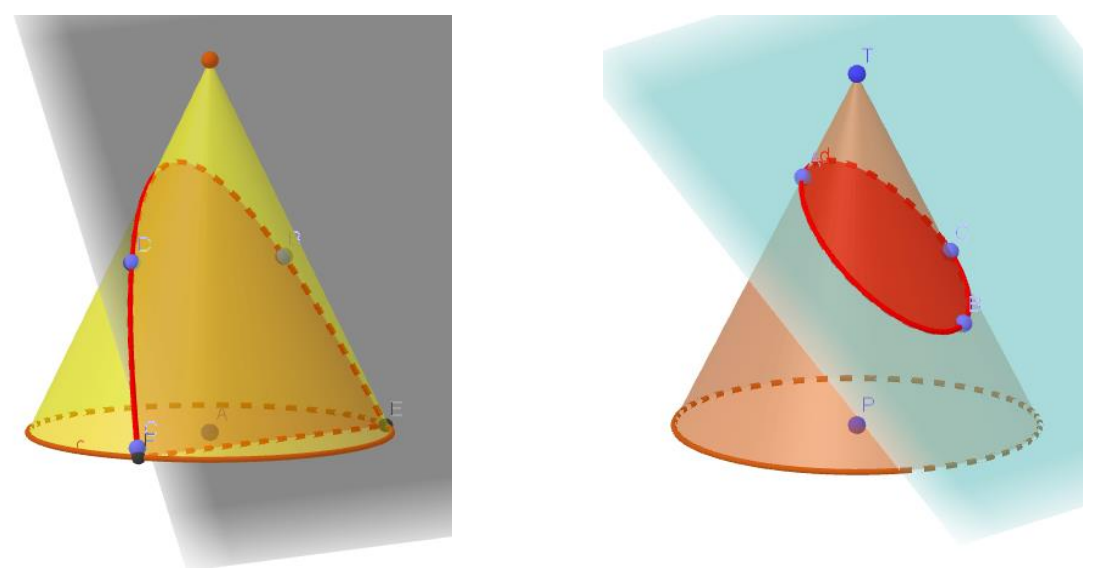

Gambar 1. Kurva Parabola \& Elips

Dari kedua tampilan di atas, dosen meminta mahasiswa mengungkap faktafakta geometris yang terlihat. Fakta-fakta yang terungkap selanjutnya dimasukkan ke dalam daftar konsep dan dijadikan dasar dalam penentuan definisi dari suatu parabola dan elips. Proses ini bertujuan untuk membangun kemampuan spasial dan penalaran visual mahasiswa yang berfokus pada penentuan secara detail tentang komponen-komponen penyusun dari suatu figur geometri dan lebih lanjut dapat menyusun suatu interpretasi/koneksi diantara komponen-komponen yang terlihat. Level berpikir di tahap ini tentu lebih dari sekedar mengetahui, namun lebih jauh telah memasuki level menganalisis dan mensisntesis suatu informasi. Proses ini dilakukan secara berkelompok dengan cara tukar pendapat/diskusi. Salah satu hasil diskusi mereka ditampilkan sebagai berikut!

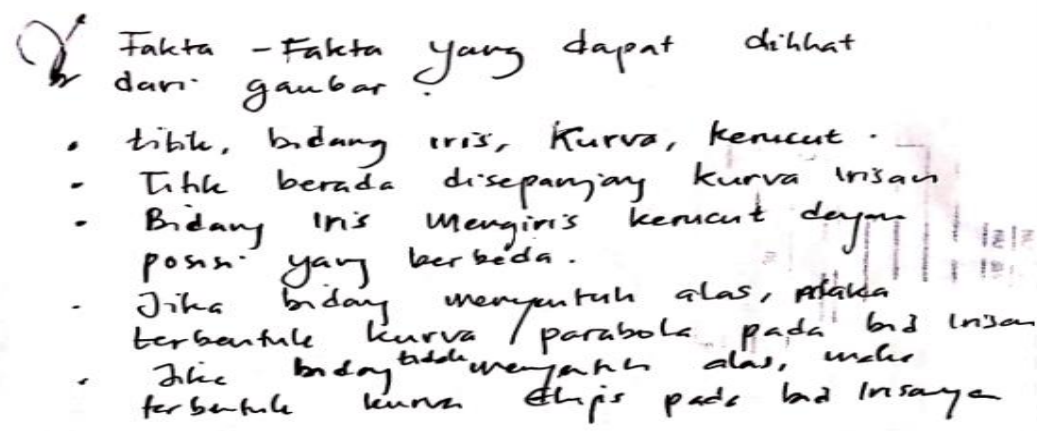

Gambar 2. Identifikasi Fakta-fakta Geometri

Dari fakta ini, mahasiswa dapat menuliskan fakta-fakta geometri berupa titik, bidang iris, kurva dan kerucut. Kurva pada daerah yang dibentuk oleh hasil irisan kerucut dengan posisi bidang iris berpotongan dengan alas kerucut akan membentuk kurva parabola. Di sisi lain, Kurva pada daerah yang dibentuk oleh 
hasil irisan kerucut dengan posisi bidang iris tidak berpotongan dengan alas kerucut akan membentuk kurva elips. Sejalan dengan temuan Krajcevski, dkk (2019) yang menjelaskan bahwa temuan kami memiliki implikasi tentang bagaimana gambar biasa dapat memengaruhi proses kognitif dan citra konsep mereka. Mengingat bahwa gambar dapat memainkan peran heuristik penting dalam memandu intuisi siswa ketika membangun argumen yang layak (bukti), atau saat memperkenalkan objek matematika, dan pemikiran yang cermat harus dibangun melalui interpretasi.

Membangun argumentasi seperti contoh di atas merupakan aktivitas mental yang rumit dan tentu membutuhkan penalaran khusus. Olehnya itu, pembelajaran geometri pada khususnya harus berorientasi pada proses pengembangan ide melalui aktivitas-aktivitas penemuan. Sejalan dengan hal ini, Fonna (2018), juga menjelaskan bahwa setiap mata kuliah dalam matematika hendaknya merupakan aktivitas yang akan membantu mahasiswa dalam pengembangan analitis, penalaran kritis, pemecahan masalah, dan keterampilan komunikasi.Untuk dapat mengkomunikasikan ide-ide matematis seseorang perlu merepresentasikan ide-ide tersebut dengan cara tertentu. Pencapaian kemampuan-kemampuan matematis mahasiswa mengalami kendala ketika mereka tidak memahami hubungan antar konsep, ide atau materi yang akan direpresentasikan. Dalam menyelesaikan permasalahan yang berkaitan dengan matematika khususnya geometri dibutuhkan kemampuan matematis yang cukup baik untuk memahaminya.

\section{b) Occupation}

Prinsip ini memuat pengintegrasian konsep-konsep (secara sistematis) menjadi suatu prinsip berdasarkan fakta yang berkembang. Inti dari aktivitas occupation adalah mahasiswa bekerja untuk menyusun suatu hubungan konsep secara sistematis. 


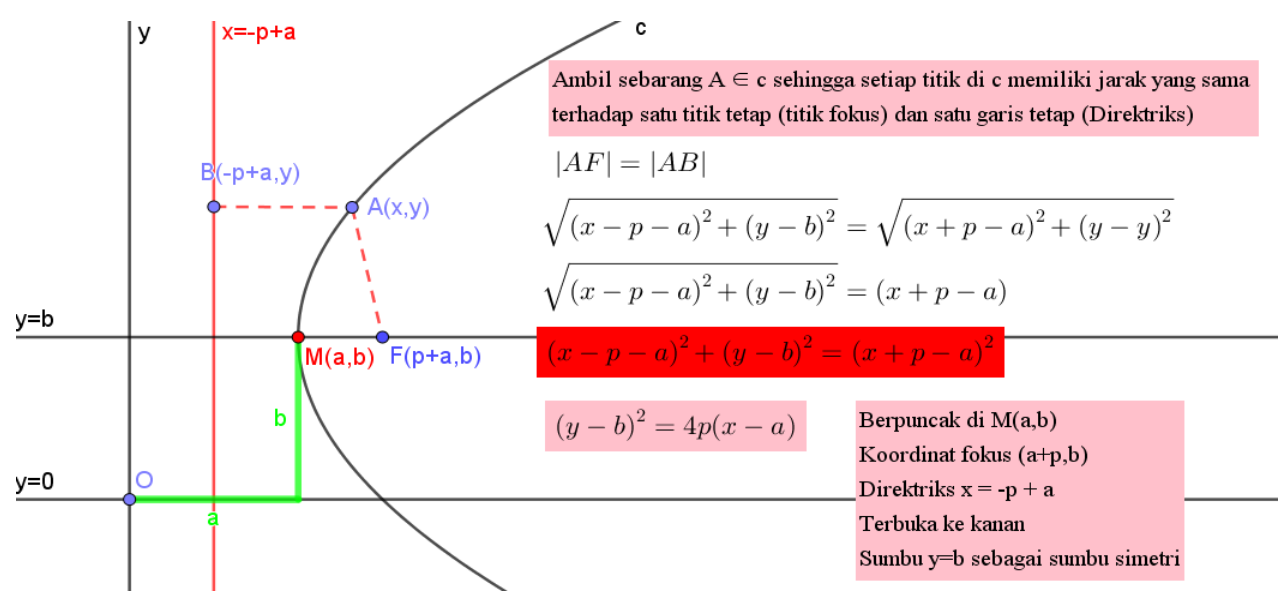

Gambar 3. Penyusunan Prinsip Parabola

Dosen memberikan sebuah gambar parabola lalu mahasiswa diminta untuk melengkapi komponen parabola serta bentuk persamaannya. Salah satu hasil pekerjaan kelompok mahasiswa di atas menjadi bukti bahwa proses occupation dalam pembelajaran geometri tidak terbatas pada pengetahuan konsep semata. Lebih luas mahasiswa dapat menyusun pemodelan sederhana tentang jarak antara sebuah titik pada kurva terhadap titik tetap (titik fokus) dan sebuah garis tetap (direktriks). Pemodelan ini dinyatakan dalam bentuk persamaan matematis yang didalamnya memuat bentuk-bentuk aljabar. Selain membutuhkan keterampilan manipulasi aljabar, pada proses ini mahasiswa juga menggunakan penalaran visual untuk menyusun prinsip-prinsip yang berlaku pada parabola pada gambar. Prinsipprinsip tersebut meliputi letak titik fokus, letak puncak, arah kurva, dan letak sumbu simetri parabola.

Berdasarkan hal ini mahasiswa dapat membuat jejaring konsep secara sistematis melalui apa yang mereka lihat dan apa yang mereka fahami. Kedua hal ini menjadi dasar bagi mereka dalam melakukan reoresentase konsep dari figural menjadi representase aljabar. Fakta ini sejalan dengan temuan Bossé (2019), yang menjelaskan bahwa representasi memuat proses penyandian ide-ide matematika, mereka melakukannya dengan hanya mengkomunikasikan ide matematika dasar, dan mungkin membangun persepsi tertentu untuk menentukan tindakan matematis dalam bentuk operasi, komunikasi, dan investigasi. 


\section{c) Analitycal}

Proses analitik dalam kajian ini meliputi proses penentuan prinsip geometri yang dimulai dari hal yang belum diketahui hingga menemukan hal-hal baru. Dosen menyajikan masalah yang belum pernah atau dibahas atau diperkenalkan sebelumnya, sedemikian hingga mahasiswa berpeluang melakukan investigasi. Bentuk investigasi yang dilakukan mahasiswa adalah dengan cara memilah-milah atau memecah-mecah informasi sehingga mendapatkan gambaran yang jelas antara bagian-bagian yang belum di ketahui dengan yang sudah diketahui. Untuk menjalankan proses ini dibutuhkan pemahaman konsep yang kuat. Hodiyanto (2019), juga menegaskan bahwa pemahaman konsep juga menjadi jembatan dalam mengembangkan kemampuan berpikir tingkat tinggi (high order thinking skill). Pemahaman matematis menempati peran penting dalam pengembangan kemampuan matematis lainnya. Dengan memahami konsep dengan benar, anda dapat membangun komunikasi matematik secara efektif berdasarkan pemecahan masalah yang melibatkan penalaran, koneksi, represetasi dan kreativitas berpikir. Berikut ditampilkan hasil analisis mahasiswa dalam penentuan persamaan parabola!
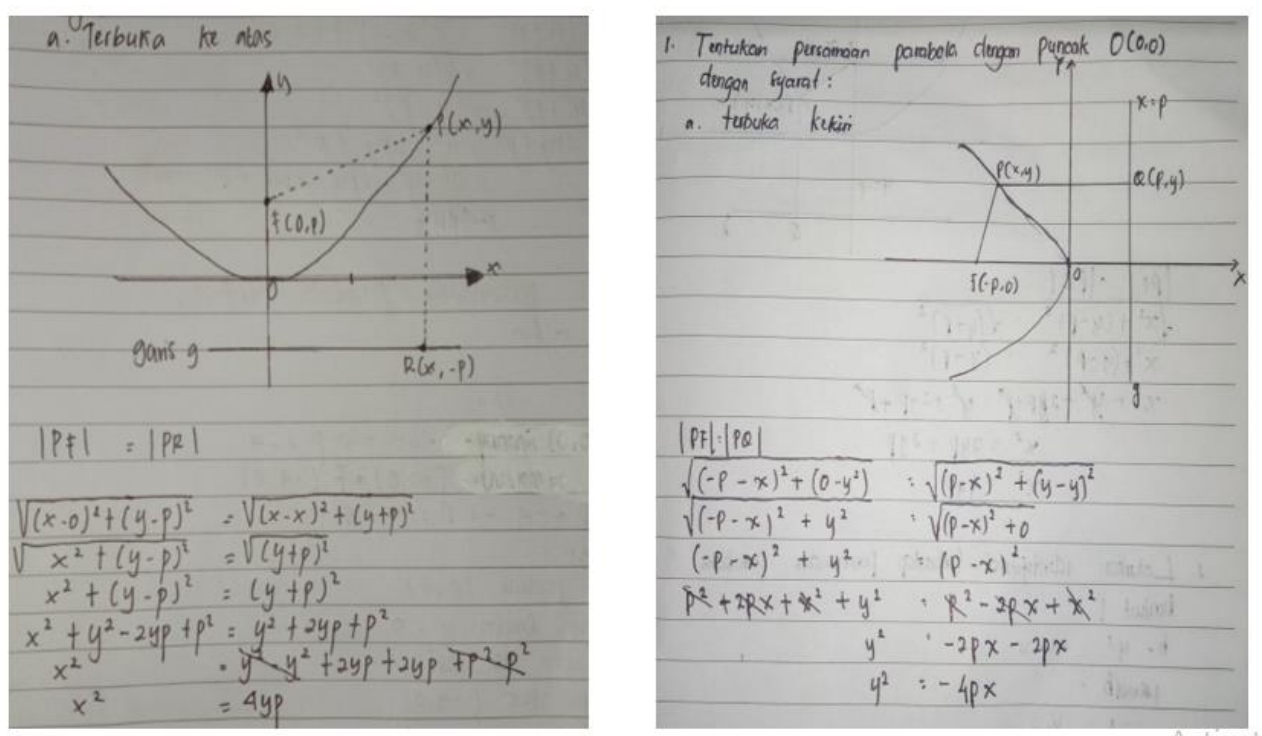

Gambar 4. Penyusunan Persamaan Parabola

Pada gambar 4, mahasiswa menentukan persamaan parabola yang terbuka ke kiri dan ke atas. Di fase sebelumnya, dosen hanya memberikan stimulus berupa prinsip parabola yang terbuka ke kiri. Perubahan arah kurva parabola juga berakibat 
pada perubahan koordinat titik puncak, titik fokus, dan direktriksnya. Hal ini belum diketahui oleh mahasiswa, namun dengan berbekal pemahaman awal yang benar mereka dapat menentukan segala kemungkinan arah kurva parabola lain baik secara geometris maupun secara analitik. Proses pengaitan ide tersebut merupakan akomodasi dalam struktur kognitif. Pasandaran dkk (2019), menjelaskan bahwa akomodasi merupakan proses pembentukan ulang struktur kognitif karena adanya rangsangan masalah baru. Dalam proses pembentukan pengetahuan baru, otak akan bekerja dengan membangun hubungan dan menentukan sangkut paut antara masalah yang satu dengan yang lainnya. Fakta ini didukung oleh temuan Gulkilik (2019), yang menjelaskan bahwa mahasiswa dapat menyusun hubungan antara argumentasi dan pembuktian pada kajian aljabar dan geometri. Fleksibilitas mahasiswa terlihat ketika mereka menunjukkan keterampilan dalam memanipulasi argumen menggunakan geometri menjadi bukti aljabar berdasarkan sudut pandang representasi. Selain representasi, analisi juga dilakukan mahasiswa dalam menentukan komponen-komponen elips melalui cuplikan sebagai berikut!
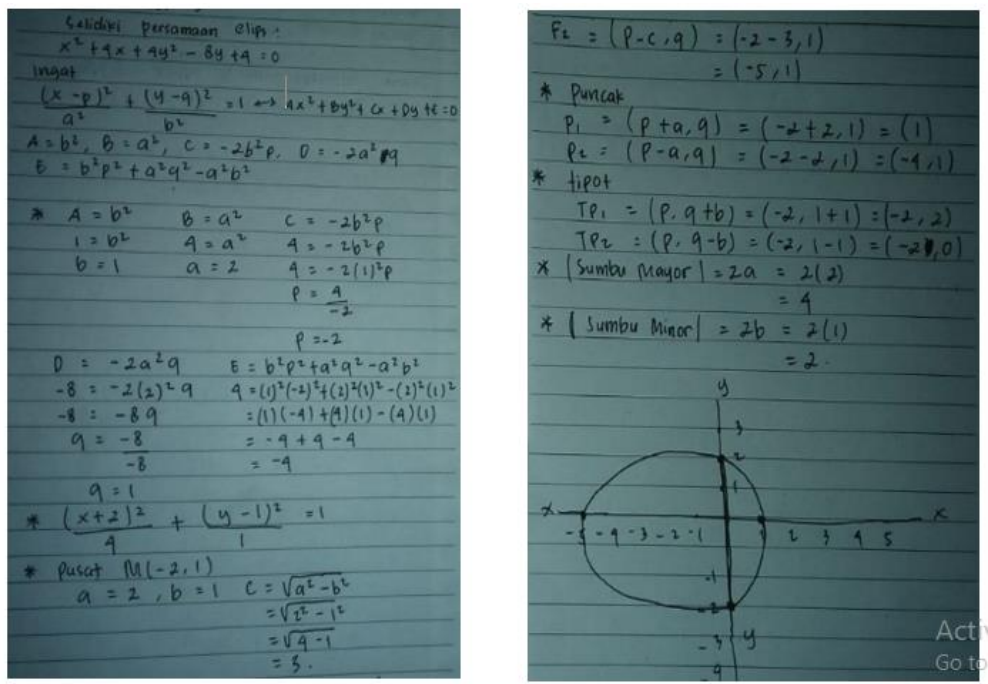

Gambar 5. Penyusunan Komponen Elips

\section{d) Learning System}

Prinsip ini memuat ilustrasi tentang sistem pembelajaran dan bentuk interaksi yang terjadi selama perkuliahan. Dosen membentuk kelompok kecil beranggotakan 5 orang. Setiap kelompok mendapatkan fasilitas belajar berupat Lembar Kerja, Bahan Diskusi, dan Soal/Pemecahan Masalah. Untuk mencapai tujuan pembelajaran, setiap kelompok diminta untuk melakukan identifikasi konsep parabola dan elips, menuliskannya ke dalam daftar konsep, memecahkan 
permasalahan yang melibatkan parabola dan elips baik secara berkelompok maupun secara individu. Adapun rincian proses pembelajaran yang dilaksanakan adalah sebagai berikut.

(a) Materi ajar yang ditetapkan adalah irisan kerucut tentang Parabola \& Elips. Tujuan pembelajarannya adalah mahasiswa dapat menyusun persamaan Parabola \& Elips serta membuktikan sifat-sifatnya.

(b) Agar materi tersebut dapat difahami mahasiswa, maka salah satu model pembelajaran yang sesuai dengan karakteristik materi adalah model pembelajaran investigasi. Model ini relevan dengan karakteristik materi karena dapat membantu mahasiswa terlibat ke dalam proses penyelidikan. Dimulai dari menyusun semua kemungkinan/dugaan, mengumpulkan informasi, hingga menemukan kesimpulan yang valid.

(c) Skenario pembelajaran disusun berdasarkan tahapan dari model pembelajaran investigasi. Dimulai dari orientasi masalah (dosen memberikan masalah untuk membangun penalaran mahasiswa), menyusun konjektur (mahasiswa memikirkan semua kemungkinan/dugaan solusi dari masalah yang diberikan), berdiskusi dan saling menanggapi (mahasiswa memecahkan masalah dalam lembar kerja, saling tukar pendapat satu sama lain), menyimpulkan dan posttest (sebagai langkah untuk menilai hasil belajar setelah melakukan kegiatan penyelidikan).

(d) Penentuan alokasi waktu pembelajaran; pretest (10 menit), (b) diskusi kelompok (60 menit), (c) presentase hasil (20 menit), posttest (10 menit).

(e) Lembar kerja yang disusun memuat aktivitas penyelidikan. Penyelidikan dilakukan melalui sejumlah petunjuk yang membantu mahasiswa mengembangkan konjektur/dugaan terkait pemecahan masalah. Teknik ini juga dikenal dengan istilah scaffolding. Proses scaffolding dilakukan secara bertahap melalui beberapa bantuan/petunjuk yang jumlahnya akan semakin berkurang seiring dengan level penguasaan konsep mahasiswa.

(f) Dosen melakukan orientasi masalah kepada mahasiswa dalam bentuk pretest. Test ini bertujuan untuk menggali kemampuan prasyarat mahasiswa, sekaligus sebagai awal kegiatan investigasi. 
(g) Dosen membagi mahasiswa ke dalam 6 kelompok, setiap kelompok beranggotakan 4-5 orang. Lembar kerja pun dibagikan untuk selanjutnya dibahas oleh mahasiswa dalam kelompoknya masing-masing. Nampak ada beberapa mahasiswa yang masih kebingungan dalam mengerjakan lembar kerja, ada juga yang kesulitan dalam melakukan manipulasi bentuk aljabar, dan ada yang tidak menguasai materi prasyarat yaitu trigonometri. Untuk itu, dosen model memberikan bantuan secara bertahap pada setiap kelompok yang tidak memahami jalan atau proses penyelesaian dari masalah yang diberikan. Setelah mahasiswa menyelesaiakan lembar kerja, beberapa mahasiswa diminta untuk mempresentasikan hasil diskusi kelompoknya untuk kemudian dibahas dalam diskusi kelas.
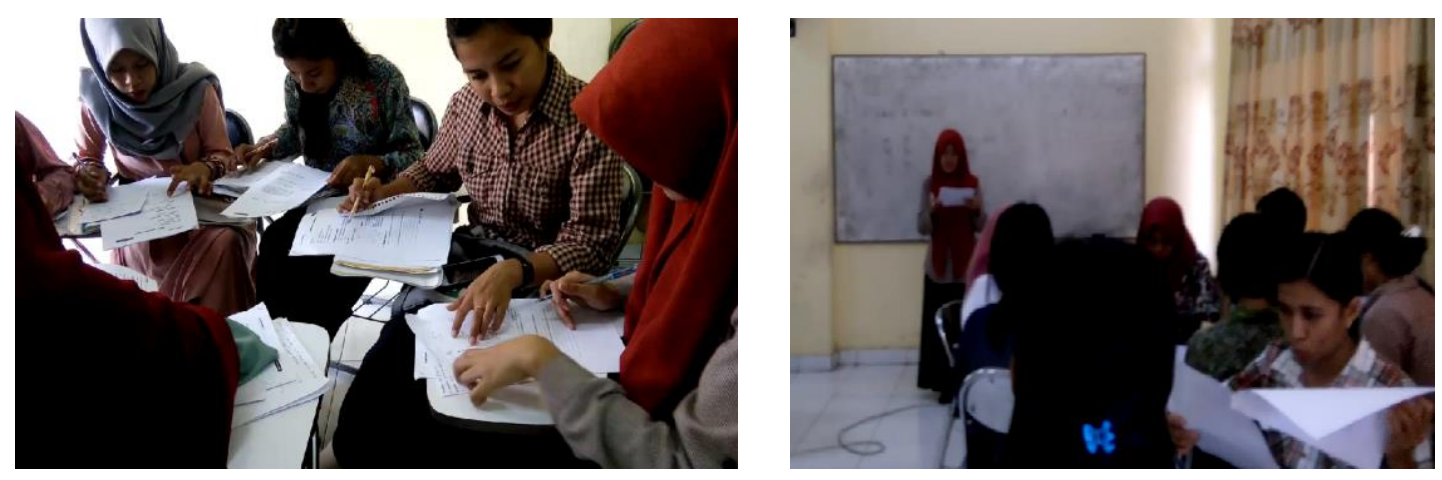

Gambar 6. Diskusi \& Presentasi

(h) Setelah membahas hal di atas, setiap mahasiswa mendapatkan posttest. Posttest bertujuan untuk mengetahui level pemahaman mahasiswa setelah melakukan penyelidikan. Adapun perbandinngan hasil pretest dan posttest mahasiswa dapat dilihat pada tabel berikut!

Tabel 1. Perbandingan Skor Pemahaman Mahasiswa

\begin{tabular}{|l|c|c|}
\hline \multicolumn{1}{|c|}{ Statistik } & Pretest & Posttest \\
\hline Rerata & 68,29 & 84,18 \\
\hline Skor Maksimum & 84 & 93 \\
\hline Skor Minimum & 53 & 76 \\
\hline Gain Score & \multicolumn{2}{|c|}{ 0,50 } \\
\hline Katgeori Peningkatan & \multicolumn{2}{|c|}{ Sedang } \\
\hline
\end{tabular}



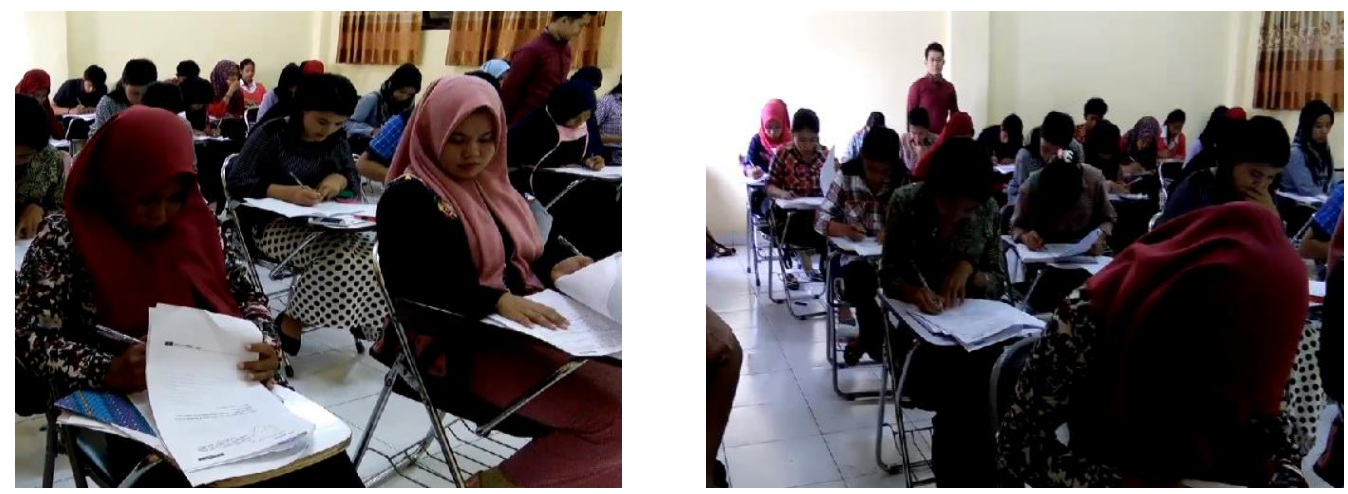

Gambar 7. Posttest

Melalui perhitungan gain score diperoleh gambaran bahwa peningkatan pemahaman mahasiswa berada pada kategori sedang. Pemahaman merupakan hal yang dinamis, rentan dengan perubahan. Sifat ini bergantung pada banyak faktor seperti halnya ketersediaan fasilitas belajar yang memadai dan dipandang sesuai dengan kebutuhan belajar mahasiswa. Seperti halnya keberadaan lembar kerja sangat membantu mahasiswa dalam melakukan investigasi secara sistematis. Sejalan dengan temuan Pasandaran dkk (2018), menjelaskan bahwa penggunaan lembar kerja dapat; (a) mengaktifkan mahasiswa dalam proses belajar mengajar, (b) membantu mahasiswa dalam mengembangkan konsep, (c) melatih mahasiswa untuk menemukan dan mengembangkan proses belajar mengajar, (d) membantu dosen dalam menyusun pelajaran, (e) sebagai pedoman dosen dan mahasiswa dalam melaksanakan proses pembelajaran, (f) membantu mahasiswa memperoleh catatan tentang materi yang dipelajari melalui kegiatan belajar, (g) membantu mahasiswa untuk menambah informasi tentang konsep yang dipelajari melalui kegiatan belajar secara sistematis.

Berdasarkan uraian di atas, diperoleh beberapa temuan yakni;

(a) Membuat jejaring komunikasi dengan sejawat mereka untuk memecahkan masalah

(b) Mengajukan dugaan dan pertanyaan ketika menyusun rencana pemecahan masalah

(c) Membantu sejawat mereka yang menemui kesulitan

(d) Mencari informasi dari berbagai sumber lain yang relevan dengan materi yang sedang dibahas 
Proses identifikasi ini bukanlah hal yang mudah. Dosen harus memiliki perspektif pengetahuan khusus yang memuat pengetahuan tentang latar belakang mahasiswa, tentang ruang lingkup materi ajar, tentang kurikulum dan tentang jenisjenis kesalahan konsep yang acap kali terjadi pada mahasiswa. Lebih lanjut, Kılıç (2011) menjelaskan bahwa dosen/guru berkualitas tinggi dan ahli tidak hanya tahu materi pelajaran, tetapi juga tahu cara mengajarkan pengetahuan tertentu. Gagasan bahwa menjadi pengajar matematika yang efektif memerlukan pengetahuan konten matematika serta pemahaman tentang proses pengajaran yang diperlukan untuk mentransfer pengetahuan ini secara efisien kepada peserta didik.

Di sisi lain, profesionalitas dosen juga berdampak pada respon mahasiswa yang memiliki kecenderungan positif terhadap pembelajaran. Respon positif mereka berupa keinginan, kesadaran, dedikasi dan kecenderungan yang kuat pada diri mahasiswa untuk berpikir dan berbuat secara matematik dengan cara yang positif. Oktaviani (2019), menjelaskan bahwa sikap dan kebiasaan berpikir yang baik pada hakekatnya akan membentuk dan menumbuh kembangkan disposisi matematik. Disposisi matematik juga turut menentukan akselerasi pencapaian hasil belajar mahasiswa. Di satu sisi, disposisi dapat mendorong motivasi mahasiswa untuk tidak mudah menyerah dalam menghadapi kendala. Di sisi lain, disposisi juga dapat membangung perasaan senang/mencintai apa yang dipelajarinya. Oleh karena itu, untuk menciptakan pemahaman dan disposisi matematis yang baik diperlukan suatu pembelajaran matematika yang berbasis kontruktivis. Sebab menurut pandangan konstruktivis, pembelajaran matematika bukanlah dipandang sebagai penyajian seperangkat fakta dan konsep yang siap diterima begitu saja oleh mahasiswa, tetapi merupakan sesuatu proses yang melibatkan siswa dalam mengkonstruksi pengetahuannya melalui bimbingan dosen.

\section{Kesimpulan}

Sifat alami geometri adalah abstrak, olehnya itu mendorong para dosen/pengajar untuk merefleksikan geometri sebagai bahan investigasi yang menarik bagi mahasiswa. Kegiatan investigasi memungkinkan setiap individu dapat membangun pertanyaan dan jawaban dalam dirinya, "mengapa? dan harus bagaimana?". Olehnya itu orientasi pembelajaran harus mengarah pada proses 
penyelidikan dengan prinsip; identifikasi semua konsep yang mendasari konstruk definisi, aksioma, atau teorema (Geometry), integrasi konsep-konsep (secara sistematis) menjadi suatu prinsip (Occupation), analisis hubungan antar konsep yang membentuk suatu prinsip (Analitycal), membangun komunikasi interaktif dan hubungan ketergantungan sosial yang positif serta mengambil peran dan tanggung jawab secara individu dan berkelompok terhadap proses penyusunan pengetahuan secara koheren (Learning System).

\section{Daftar Pustaka}

Bossé , M. (2019). Mathematical Representational Code Switching . International Journal For Mathematics Teaching And Learning 2019, Vol. 20.1, 33-61, 37.

Fonna, M. (2018). Pengembangan Modul Geometri Analitik Bidang Berbantuan Wingeom Software Studi Pendidikan Matematika Universitas Malikussaleh. Proceeding Seminar Nasional Politeknik Negeri Lhokseumawe, (hal. 1). Lhokseumawe .

Gulkilik, H. (2019). Investigating the Relationship between Argumentation and Proof from a Representational Perspective. International Journal For Mathematics Teaching And Learning 2019, Vol. 20.2, 131-148, 131-148.

Hodiyanto. (2019). Geometer's Sketchpad (GSP) dan Pemahaman Konsep Geometri Analitik Bidang. Jurnal Matematika Kreatif-Inovatif Kreano 10 (2) (2019), 153-158.

Kıliç, H. (2011). Preservice Secondary Mathematics Teachers' Knowledge of Students. Turkish Online Journal of Qualitative Inquiry, April 2011, 2(2), 19.

Krajcevski , M. (2019). Common Visual Representations as a Source for Misconceptions of Preservice Teachers in a Geometry Connection Course . International Journal For Mathematics Teaching And Learning 2019, Vol. 20.1, 85-105, 1.

Nur'aini, I. (2017). Pembelajaran Matematika Geometri Secara Realistis. Jurnal Matematika Vol.16 No.2, 1-2.

Oktaviani, D. N. (2019). Kemampuan Disposisi Matematik Mahasiswa Pada Mata Kuliah Geometri Analitik. Jurnal Ilmiah Pendidikan Matematika Volume 5 Nomor $1,77$.

Pasandaran, R. F., Jumarniati. (2019). Eksplorasi Budaya Literasi Matematika Pada Mahasiswa Calon Guru. Pedagogy Volume 4 Nomor 1, 65. https://www.journal.uncp.ac.id/index.php/Pedagogy/article/view/1430 
Pasandaran, R. F., Masni, E. D., \& Kartika, D. R. (2018). Pengembangan Lembar Kerja Mahasiswa (Lkm) Pada Pembuktian Dalil-Dalil Segitiga. Prosiding Seminar Nasional ISSN 2443-1109. 03, hal. 148. Palopo: UNCP Press.

https://www.journal.uncp.ac.id/index.php/proceding/article/view/783 